Versions of a Feminine Voice: The Compiuta Donzella di Firenze

David Bowe

Somerville College, University of Oxford, Oxford, UK

Post: Somerville College, Oxford. OX2 6HD. Telephone: 07503 972272. Email:

david.bowe@mod-langs.ox.ac.uk. Twitter:@NotQuiteZiggy 


\section{Versions of a Feminine Voice: The Compiuta Donzella di Firenze ${ }^{1}$}

This article offers a detailed reading of the surviving sonnets of the poet known as the Compiuta Donzella di Firenze, paying particular attention to her performance of a gendered subject and critical engagement with common lyric tropes. A lack of bibliographical information about the Compiuta Donzella, the first woman to whom literary texts in the Italian vernacular are attributed, has led to speculation over her identity and 'authenticity' or biographical readings of her texts. Acknowledging the same sorts of playful, ironic, and performative lyric subject and content in the Compiuta Donzella's work that are commonly ascribed to other lyric voices allows us to appreciate the technical and thematic artifice in her sonnets. Comparative close reading of her surviving texts and some responses to them (by Guittone d'Arezzo, Maestro Rinuccino or Guido Guinizzelli, and an anonymous poet) provides a broader perspective on her work as engaged in active dialogue with the lyric context of thirteenth-century Italy.

Keywords: Compiuta Donzella, gender performance, Guittone d'Arezzo, Guido Guinizzelli, lyric poetry, Duecento

\section{Introduction}

In Italy, a highly praised pseudonymous woman writer's skilful portrayals of the cultural and domestic struggles of highly literate women in misogynist contexts are making

1 The material in this article was originally presented at the 'Dante and Origins' study day at the University of Bristol in 2015 and later in a seminar at NYU in 2016. I am grateful to the participants in both occasions and to the anonymous readers at Italian Studies for their incisive, constructive comments. 
waves. ${ }^{2}$ With no biographical information except a city of residence, readers and critics speculate over her identity, even attributing her work to a man. This is not the clamour over recent years around the 'true' identity of Elena Ferrante, but a history of the reception of the Compiuta Donzella di Firenze. That there should be such an anxiety of authorial identity evident in articles about and reviews of Ferrante's work might be surprising in this, our post-Barthesian age, but the determination of some to 'out' her 'true' identity reached fever pitch in late-2016. The Compiuta Donzella has suffered in the face of similar anxieties, which have often led either to her identity as a woman writing being erased for lack of extra-textual biography, or to her work being valued only in as far is it serves as 'authentic' biography. These are both phenomena which a careful reading of her poetry in its contexts readily resists. Problematising the conflation of feminine voice and woman writer into a single biographical unit is at the heart of Matilda Tomaryn Bruckner's study, 'Fictions of the Female Voice: The Women Troubadours', from which the present article adapts its title. Bruckner notes that 'by manipulating that

2 A note on terminology: I will refer to the Compiuta Donzella as a 'woman poet/writer', for the simple reason that her texts are ascribed to a woman in their manuscript witness. I also wish to place the present study in dialogue with other scholarship on (early) women writers-see, for example, Strong Voices, Weak History: Early Women Writers and Canons in England, France, and Italy, ed. by Pamela Joseph Benson and Victoria Kirkham (Ann Arbor: University of Michigan Press, 2004). The Compiuta Donzella also presents us with a speaker who is a young woman within the context of medieval social and gender norms, and I will refer to this voice/speaker as 'feminine' (and thus to other voices as 'masculine') in light of discussions of gender performance, and with reference to the helpful framework established in the treatment of Christine de Pizan and men writing in the querelle des femmes tradition, in Helen Swift, Gender, Writing and Performance: Men Defending Women in Late Medieval France (Oxford: Oxford University Press, 2008), especially pp. 172-226. Concomitantly, I will avoid default male usages of terms relating to authorship and subjectivity; any aesthetic discomfort created by this usage hopefully serves to reinforce the anxieties of poetic identity and scholarly language in play. 
system [of troubadour lyric] and its constraining voices, the trobairitz invented their own distinctive and quite varied fictions of the female voice'. ${ }^{3}$ The present article seeks to show how, through turning features of the Italian lyric system back on themselves, the texts attributed to the Compiuta Donzella present not just a critique of lyric tropes, but also new versions of a feminine voice for a thirteenth-century Florentine context.

Three texts are preserved in the so-called Vatican Canzoniere, attributed to one Compiuta Donzella (di Firenze). ${ }^{4}$ They are notable for being the only poems in the manuscript both ascribed to a woman, and written from the perspective of a feminine 'I'. Texts written in feminine voices, however, are far from rare in this manuscript anthology. The Vatican Canzoniere contains many examples of poets who are men writing in ventriloquised feminine voices, both in the course of political and homosocial debate, and in the context of tenzoni fittizie, dialogues with an invented female interlocutor. 5 The striking difference of the Compiuta Donzella's sonnets in this context, is that, unlike those ventriloquised and fictitious voices, they are not ascribed to a man (as, for example Guittone d'Arezzo's tenzone fittizia with a 'villana donna', in which the poems in both masculine and feminine voices are ascribed to 'Guittone medesimo' throughout, Vat. Lat. 3793 f. 150r-v) or left anonymous, but instead are ascribed to a woman, a unique phenomenon in the manuscript. Early scholarship around the Compiuta Donzella di Firenze fell largely into two camps: one announcing her identity as a poet who was a

\footnotetext{
${ }^{3}$ Matilda Tomaryn Bruckner, 'Fictions of the Female Voice: The Women Troubadours', in Speculum, 67.4 (1992), 865-91 (p. 868).

4 Vatican Library, MS Vaticano Latino 3793. The rubrics read 'Lacompiuta donzella difirenze', Lacompiuta medesima' (f. 129v), and 'Compiuta donzella' (f. 170r), respectively.

5 See the discussion of the 'donne' in MS Vat. Lat. 3793 in Justin Steinberg, Accounting for Dante: Urban Readers and Writers in Late Medieval Italy (Notre Dame: University of Notre Dame Press, 2007), especially pp. 66-73.
} 
woman, by dint of dubiously essentialist rhetorical and aesthetic judgments (e.g. the 'more perfect simplicity of the feminine sonnet' once suggested by Francesco De Robertis), ${ }^{6}$ the other denying that identity based on flimsy, circular arguments around the scarcity of women poets in the Duecento. ${ }^{7}$ More involved studies in the last three decades have engaged with some of the content and a good deal of the context of the Compiuta Donzella's poems, and have offered less categorical responses to the question of her identity.

Paola Malpezzi Price has noted the historical tendency of scholarship to erase the presence of early women writers in relation to the particular case of the Compiuta Donzella. Steinberg, meanwhile, in by far the most detailed engagement with the Compiuta Donzella's texts, treats the Compiuta Donzella in the context of the 'voce femminile' in the Vatican Canzoniere. He brings out the anxieties of men poets in the presence of a feminine voice that cannot simply be ascribed to another man's ventriloquism and highlights the importance of this same voice in contributing to the critique of courtly language that runs through the codex. Paolo Cherchi offers something of a historiography of arguments around the existence of the Compiuta Donzella. While he approvingly quotes Gianfranco Contini's assertion that there is 'no serious reason to reject the Compiuta Donzella's historical reality', the conclusion of his essay implies that he tends

6 'La più perfetta simplicità del sonetto femminile', Francesco De Robertis, Storia della letteratura italiana, 2 vols (Naples: Morano, 1935-1936), II, p. 26.

${ }^{7}$ Adolfo Borgognoni, 'Rimatrici italiane dei primi tre secoli', in Studi di letteratura storica (Bologna: Zanichelli, 1891), pp. 161-202: 'Le donne italiane di que' secoli, anche le nobili ed eleganti, da tutto quel che ne sappiamo, non pare aspirassero al vanto di letterate e di poetesse'. Borgognoni was also author of a violently misogynistic article arguing against the existence of the Nina Siciliana: Borgognoni, 'La condanna capitale d'una bella signora', Studi d'erudizione e d'arte, 2 (1878), 89-105. 
towards rejection nonetheless. Guido Mazzoni offers virtually no engagement with the texts, but suggests that the Compiuta is probably a man ventriloquising a feminine voice, albeit a voice which may recall a historical young woman of some repute, whose characteristics became idealised and turned into a poetic trope. Stefano Carrai presents something of an exception in embarking on his analysis, with the underlying assumption that the Compiuta Donzella is a woman and the author of her texts. Carrai's analysis focusses on the structural circularities in the so-called 'diptych' of 'A la stagion che '1 mondo foglia e fiora' and 'Lasciar vor[r]ia lo mondo e Dio servire', prioritising the role of rhetorical variation in the treatment their shared themes (resistance to marriage and the clash of wills with the speaker's father). ${ }^{8}$

The present study proceeds on the understanding that these texts can be attributed to a poet who was a woman, though does not take this as the cue for unduly bio-

8 Paola Malpezzi Price, 'Uncovering Women's Writings: Two Early Italian Women Poets', The Journal of the Rocky Mountain Medieval and Renaissance Association, 9 (1988), 1-17 (pp. 1-4). Steinberg, 'La Compiuta Donzella e la voce femminile nel manoscritto Vat. Lat 3793', Giornale Storico della Letteratura Italiana, 183 (2006), 1-31. Paolo Cherchi, 'The Troubled Existence of Three Women Poets', in The Voice of the Trobairitz: Perspectives on the Women Troubadours, ed. by W. D. Paden (Philadelphia: University of Philadelphia Press, 1989), pp. 198-209, quoting Poeti del Duecento, ed. by Gianfranco Contini, 2 vols (Milano: Riccardo Ricciardi Editore, 1960), I, p. 433. Guido Mazzoni, 'I fedeli d'amore e la Compiuta Donzella', in Almae luces, malae cruces: Studi danteschi (Bologna: Zanichel1i, 1941), 149-56 (pp. 150-51). Stefano Carrai, 'Il dittico della Compiuta Donzella', in Medioevo romanzo, 17 (1992), 207-13. For a summary of interventions, see Daniele Cerrato, 'Nuove Ipotesi su Compiuta Donzella', Estudios Románicos, 23 (2014), 105-16 (p. 107), though Cerrato is primarily invested in tracking a hypothetical biography for the woman who wielded the pen. Special mention should go to Lorenzo Valli, Il linguaggio segreto di Dante e dei 'fedeli d'amore' (Rome: Biblioteca di Filosofia e Scienza, 1928), pp. 247-50, for a conspiracy theory treating the Compiuta Donzella as a cipher and the 'fedeli d'amore' as a religious sect. 
graphical readings. ${ }^{9}$ A large proportion of readings of the Compiuta Donzella's work have focussed primarily on a restricted number of texts within an already restricted corpus: the so-called diptych of 'A la stagion che 'l mondo foglia e fiora' and 'Lasciar vor[r]ia lo mondo e Dio servire' (united by their theme of resistance to marriage in the face of a father's plans), treating her tenzone with an anonymous masculine interlocutor as an outlier. 10 There is still ample room to engage in detailed analysis of all three of these texts qua texts and I propose to undertake just such a reading to highlight the rhetorical gambits with which the poet performs her feminine subjectivity. Along the way, this article will also touch upon the status of the Compiuta Donzella as a woman poet and on some earlier readers and readings of the Compiuta Donzella. This latter category includes apparent responses to her by contemporary and near-contemporary readers and

\footnotetext{
${ }^{9}$ Cherchi, p. 209, highlights the importance of resisting any tendency to seek 'autobiographic elements in the poems of this elusive young lady' echoing the anti-autobiographical assertion of Marina Zancan, 'La donna', in Letteratura italiana: Le questioni, ed. by Alberto Asor Rosa (Turin: Einaudi, 1986), pp. 765-811, (pp. 781-82).

${ }^{10}$ Roberto Crespo, 'La Compiuta Donzella', in Medioevo romanzo, 13 (1988), 203-22, focusses on the perceived failings of the Compiuta Donzella's poetry within the narrow rhetorical confines of expositio. Carrai, 'Il dittico', pp. 207-13, focusses on what he perceives as almost inter-strophic connections between the 'diptych' of 'A la stagion' and 'Lasciar vor[r]ia'.
} 
correspondents. ${ }^{11}$ The primary focus of this article, however, will remain the detailed analysis of the Compiuta Donzella's sonnets in order to better understand the poetic voice she performs in them and the ways in which that performance playfully engages with and subverts some of the generic norms and assumed power dynamics of lyric poetry and thirteenth-century Florentine society.

Of these three sonnets by the Compiuta Donzella, two deal with the issue of forced marriage, albeit in rather different contexts, and these will be treated in part one of this article. The first, 'A la stagion che 'l mondo foglia e fiora', laments that, while lovers take pleasure in the spring and each other, the poet is left to suffer because of her father's plans to make her marry. The second, 'Lasciar vor[r]ia lo mondo e Dio servire'

11 The catalogue of texts read as addressing or responding to the Compiuta Donzella comprises: a prose letter by Guittone d'Arezzo (discussed below); two sonnets now attributed to Maestro Rinuccino ('Gentile e sagia donzella amorosa', 'Donzella gaia e sagia e canoscente'), and one attributed variously to Rinuccino or Guido Guinizzelli ('Gentile donzella, di pregio nomata', in Contini, I, 474); two further anonymous sonnets ('Gentil donzella somma ed insegnata' and 'Perc' ogni gioia ch'è rara è graziosa') in tenzone with the Compiuta Donzella's sonnet, 'Ornato di gran pregio e di valenza'; Maestro Torrigiano's two sonnets, 'Esser donzella di trovare dotta' and 'S'una donzella di trovar s'ingegna' (Contini, I, 439-440); a canzone in the feminine voice, 'Orato di valor dolze meo sire', also found in MS Vat. Lat. 3793, attributed to Chiaro Davanzati in Rime, ed. by Aldo Menichetti (Bologna: Commissione per i testi di lingua, 1965), pp. 64-67-it has even been suggested that this might also be by the Compiuta Donzella, Cerrato, p. 113, citing Liborio Azzolina, 'La Compiuta Donzella di Firenze', in Antologia Siciliana, 9 (1902), 3-43); and possibly also Graziolo Da Fiorenza's sonnet 'Gli occhi, che son messaggi lo core' (recently argued in Cerrato, p. 113). She may also appear in an illustration to Francesco da Barberino's early 14th-century Documenti d'Amore among the victims of Amor: a Latin passage in which a young woman follows 'amor divin[us]' to extreme lengths, against her parents' wishes, glosses an image of a 'donçella com[p]iuta' and the speech attributed to her; I documenti d'amore di Francesco da Barberino secondo i mss. originali, ed. by Francesco Egidi, 4 vols (Rome: Società Filologica Romana, 1924), III, pp. 407-17. Steinberg, 'La Compiuta Donzella', p. 22-25, discusses many of these responses and their relation to and representation of the 'figure of the Compiuta donzella' [sic] (p. 22). 
declares her desire for a life of religious enclosure instead of marriage. The other sonnet, 'Ornato di gran pregio e di valenza', which will form the focus of the second part, was written in response to an anonymous interlocutor, and adopts a tone of apparently modest acceptance of praise, befitting its dialogic context, but which may yet mask a hint of destabilising irony.

\title{
Subjectivity and subjection
}

In 'A la stagion', the Compiuta Donzella conjures an idyllic and familiar courtly world, drawing on generic tropes of spring as a time for lovers:

\author{
A la stagion che 'l mondo foglia e fiora \\ acresce gioia a tutti fin'amanti, \\ e vanno insieme a li giardini alora \\ che gli auscelletti fanno dolzi canti; \\ la franca gente tutta s'inamora \\ e di servir ciascun tragges'inanti, \\ ed ogni damigella in gioia dimora; \\ e me, n'abondan marrimenti e pianti. \\ 'A la stagion', 1-812
}

The octave introduces one of this sonnet's more prominent rhetorical features, the pairings of 'foglia e fiora', which will return with a negative spin in the sestet, and 'marri-

12 The Compiuta Donzella's texts are quoted according to d'Arco Silvio Avalle, Concordanza della lingua poetica italiana delle origini (Milan: Ricciardi, 1992). 
menti e pianti'. ${ }^{13}$ Before any first-person pronouncements are made by the speaker, the first quatrain plants a garden with flourishing greenery and furnishes it with lovers and singing birds. The second populates it with the people who witness this idyllic locus amoenus, portraying them through the accumulation of descriptive phrases through polysyndeton ('e $[\ldots]$ ed $[\ldots]$ e' (6-8). Those who are free enjoy the amorous season are introduced in lines 4-7, while a sour note is struck in line 8 as the speaker interjects with a bitter lament in contrast to the sweetness of spring. But these lines also set the scene for a less obvious gambit, which hinges on a rhetorically calculated deployment of the speaker's gender. It may initially seem counterintuitive to have the third 'and' ('e me, n'abondan in marrimenti e pianti', 8) taking on an adversative, rather than a cumulative function here, shifting attention away from the joys of lovers in spring to the suffering of the poet. We would expect this contrastive change of direction to come in the sestet, but the Compiuta Donzella is setting up an altogether different opposition. Rather than the generic lover's plaint in the face of others' joys, the Compiuta Donzella uses the sestet to contrast the state of the feminine speaker with that of the traditional, masculine figure of the courtly poet. ${ }^{14}$ The generic, choral io of a cliché-ridden lyric mode will be replaced by a specified speaker, defined in terms of gender, power dynamics, and will:

Ca lo mio padre m'ha messa 'n errore,

13 This repetitive circularity is the focus in Carrai, 'Il dittico'.

14 On this point my reading sides with Steinberg, 'La Compiuta Donzella', p. 19 (who notes the unexpected revelation of the feminine speaker, in place of the masculine lament in line 9), and diverges from the 7-7 symmetrical bipartition suggested by both Crespo, p. 203, and Christopher Kleinhenz, 'Pulzelle e maritate: Coming of Age, Rights of Passage, and the Question of Marriage in Some Early Italian Poems', in Matrons and Marginal Women in Medieval Society, ed. by Robert Edwards and Vicky L Ziegler, (Woodbridge: Boydell and Brewer, 1995), pp. 89-110 (p. 90). 
e tenemi sovente in forte doglia:

donar mi vole a mia forza segnore,

ed io di ciò non ho disìo né voglia,

e 'n gran tormento vivo a tutte l'ore;

però non mi ralegra fior né foglia.

'A la stagion', 9-14

The Compiuta Donzella's adversative moment consists not just in creating a commonplace contrast between her suffering and the joyous season, but in juxtaposing the suffering of a feminine-gendered speaker in a medieval social context of male power with that of the masculine lover and the mode of courtly love lyric. The courtly lover laments his torment by a proud, disdainful lady; the Compiuta Donzella's speaker laments that she is tormented by her father's authority over her marital fate. The lover complains of the power of Lord Love- the anthropomorphic Amore as Signore; the Compiuta Donzella's speaker weeps over being given over, against her wishes, to the power of a human 'lord', the husband who will have domestic power over her. The generic lover's torments result from unrequited love or an overwhelming physiological response to the experience of passion; the torments of the speaker in 'A la stagion' come from the fear of an unwanted match and absence or denial of personal agency and social power. Subjectivity and subjection play out in parallel, as the feminine speaker is initially presented only as the object of verbs, never their agent ('m'ha messa', 'tenemi', 'donar mi vole'). This speaker crystallises around the loss of power in the face of a patriarchal marriage system, and it is only in the second tercet that she takes subjective control of the verbs. 
This syntactical movement from object to subject, however, does not herald much in the way of an improvement in the speaker's state, as the primary focus of the these firstperson verbs is a negative one: on what the speaker does not want ('non ho disio né voglia') or suffers ('"n gran tormento vivo'). This negatively defined subject does then allow one act of syntactical resistance: as the opening scenario is finally restated the speaker, returned to the position of object pronoun, now takes on a negatively inflected, active resistance to the cheering powers of spring, revisited at the poem's close in the cyclical recapitulation of 'non mi ralegra fior né foglia'.

The deployment of the first-person speaker in moments of restriction and resistance serves in part to highlight the normative structures of authority at play in the medieval household, as well as the generic norms of lyric poetry. ${ }^{15}$ The power dynamics of courtly love may be conjured and dismissed in a textual instant, the sonnet suggests, and they pale in comparison to the social reality facing young women like the speaker. This is not to claim 'A la stagion' as biographical record, there is no more reason to suppose that the Compiuta Donzella is documenting the ins and outs of her own undesired marriage than there is to believe that Dante ever had a genuine vision of Love feeding his burning heart to a young woman draped in nothing but a red cloth. ${ }^{16}$ Just as there is a tradition of the enigmatic lover's vision on which Dante plays, so is there a genealogy of lyric representations of unhappy marriages and filial resistance to parental wishes. A key difference though, is that while vision poems allowed for poetic discussion, ex-

\footnotetext{
15 Steinberg notes how this unexpected entry into a domestic sphere highlights the structural hypocrisy of the courtly world, 'La Compiuta Donzella', p. 17.

${ }^{16}$ As recounted in the sonnet 'A ciascun alma presa', and subsequently the Vita nova (III.10-12).
} 
change, and no little ribaldry, the scene portrayed in the Compiuta Donzella's text does reflect the historical circumstances of paternally orchestrated marriage contracts. 17

The Compiuta Donzella's sonnet is not simply a reinforcement of the patriarchal authority that it laments, however. On the rhetorical level it ironises and undermines the lexis of courtly complaint, precisely by bringing into sharp focus the more pressing significances of lordship, power, and suffering at the hands of another which make up the linguistic game of the courtly universe. The gendering of the speaker as feminine, delayed as it is until the sestet, renders the second quatrain parodic, making a mockery of courtly clichés and particularly of the figure of the sighing lover, who lacks power only in as far as a lady will not bow to his wishes. In a rebuttal to the representations of proud ladies in many a courtly exchange, the Compiuta Donzella stages a resistance to both suitor and father confected from the same rhetorical stuff as male-centred lyric commonplaces.

In the Compiuta Donzella's second poem, 'Lasciar vor[r]ia lo mondo e Dio servire', we find a sonnet which troubles the courtly universe in a related, but slightly different manner. It is not clear that this poem forms an indissoluble diptych with 'A la stagion', as Carrai has argued, ${ }^{18}$ but there are evident thematic and rhetorical links between the texts which allow us to consider them as discursively related. ${ }^{19}$ Not least

17 On the tradition of this trope (known as mal-mariée/malmaritata) and the Compiuta Donzella's engagement with it, see Kleinhenz, pp. 89-91 \& p. 107; on marriage practices, see David Herlihy, 'The Medieval Marriage Market', in The Social History of Italy and Western Europe, 700-1500 (London: Variorum Reprints, 1978) XIV, pp. 3-21, and bibliography in Julius Kirshner, Marriage, Dowry and Citizenship in Late Medieval and Renaissance Italy (Toronto: University of Toronto Press, 2015).

18 Carrai, 'Il dittico', pp. 207-210.

19 Possibly even as remnants of a larger, lost sequence, though this speculative proposition is necessarily relegated to the footnotes. 
among these is the language of service and lordship, already present in 'A la stagion', the former in generic courtly terms of the desire to 'servir' a lover, the latter in relation to the unwanted husband, portrayed as 'segnore' in the first sonnet and as 'sire' in this one.

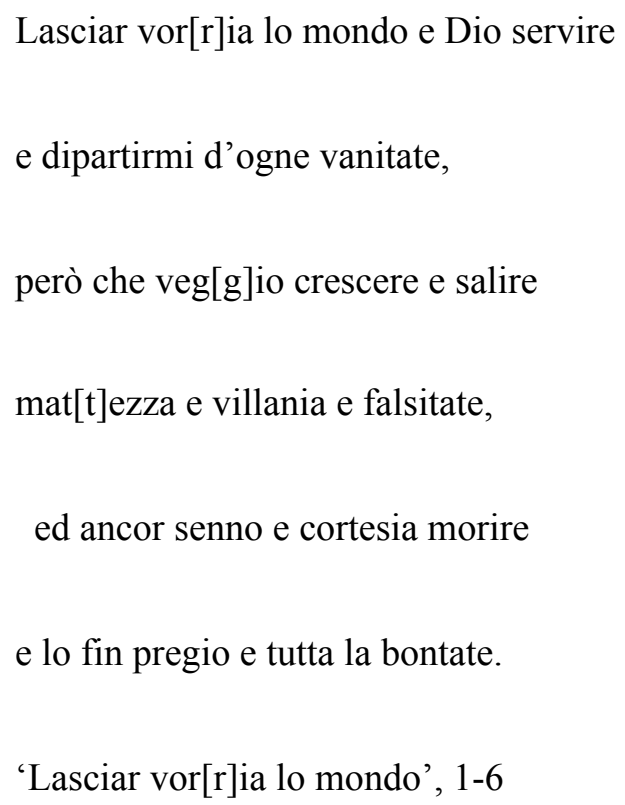

These first six lines embark on a morally charged invective comparable with Frate Guittone's more stentorian verse and Dante's lyric railing against the flight of courtly virtue from the world in 'Doglia mi reca' ${ }^{20}$ Indeed the desire to turn to God in the face of such a sea of discourtesy, madness, and falsehood, recalls the vocabulary with which Frate Guittone characterises his own courtly past, the problems of earthly love, and human evils. In 'Altra fiata aggio già, donne, parlato', the friar-poet claims that he has wronged women through his 'mattezza'. ${ }^{21}$ In 'Ahi, quant'ho che vergogni e che doglia aggio', meanwhile, the whole age ('secol', 48) is classed as a place of brutishness and falsity

${ }^{20}$ This latter comparison is made by Simon Marchesi, 'Compiuta Donzella', in Encyclopedia of Italian Literary Studies, ed. by Gaetana Marrone, Paolo Puppa, and Luca Somigli (London: Routledge, 2007), pp. 505-06.

${ }^{21}$ Reference edition: Le rime di Guittone d'Arezzo, ed. by Francesco Egidi (Bari: Laterza 1940). 
('loco è de bruttezza e de falsìa', 49). In 'O tu, de nome amore, guerra de fatto', Guittone also shares the Compiuta Donzella's concern with lies in place of truth ('in loco di gran ver menzogna', 7), and shame in place of honour (in loco d'onor propia vergogna', 8).

By appropriating this didactic vocabulary in 'Lasciar vor[r]ia', the Compiuta Donzella positions herself as a figure of moral authority, and, as in 'A la stagion', the gender of the subject is revealed only belatedly, after the development of a scenario that might as easily be recounted by a masculine speaker. It is only after she has identified all the ills of society that the speaker is situated in a gendered way, and we are led to realise that her moral stance is also being posited as argument both for religious enclosure and against marriage:

ond'io marito non vor[r]ia né sire,

né stare al mondo, per mia volontate.

'Lasciar vor[r]ia' 7-8.

The speaker is first revealed as a woman in relation to the husband that she does not want, and in almost the same breath the pronoun 'io' first enters the scene, introducing the speaker's subjectivity. Once more, the lyric language of lordship ('sire') takes on a different tenor in the voice of a feminine speaker who finds herself in a position of diminished autonomy, her will sidelined by her circumstances through a process akin to 
the pronomial play of 'A la stagion'.22 The variations on volere/volontate, and the thematic recapitulation of the opening line's desire to leave the world in these lines, tie together the beginning and end of this octave and emphasise both the strength and the compromised experience of her will. This thematic exploration of willing and not willing is another echo of 'A la stagion', which contrasts the father's will ('donar mi vole') with the speaker's ('non ho disio né voglia'). Furthermore, the notions of will and what is willed are counterposed in a structural chiasmus, which shapes the octave: the opening two lines give an account of what the speaker wants ('Lasciar vor[r]ia') while the final two lines focus on that which she does not want ('marito non vor[r]ia'). Similarly, lines 3-4 present her reasons for wishing to leave the world and serve God, while lines 5-6 lay out the rationale for her distaste for marriage. The whole octave turns on the speaker's declarations about her will.

The sestet will also follow a related structural programme, established by questions of agency (however compromised), as lines 9-11 focus on what the io does, while lines 12-14 illustrate what is done to her. The speaker's frustrated experience of agency does not dampen her moral judgements, though, as the sestet, marked by a shift from

22 The situation and language of the will recalls Dante's encounter with Piccarda, whose explanation of her divine bliss in Paradiso III turns on the concept of 'voluntade' and its cognates, expressed in a nutshell in " E' 'n la sua [God's] volontade è nostra pace" (Par. III, $85)$. Though this is not the place for a full scale comparative reading of the two figures, there do seem to be significant parallels between the two young women- 'donzella' and 'giovinetta' (Par. III, 103) respectively - wishing to leave the world, or managing to leave it to join a convent—'Lasciar vor[r]ia lo mondo', 'Dal mondo [...] fuggi'mi' (Par. III, 103-4). Both, however, are ultimately prevented from pursuing that life by men-'Lo padre mio [...] a Cristo mi distorna', 'Uomini poi, a mal più ch'a bene usi, / fuor mi rapiron de la dolce chiostra' (Par. III, 106-7). The glossing of Dante's Piccarda in the commentary tradition to the Commedia reinforces the resonance between these scenarios. 
the uncertain conditional to the assertive gerund and simple present, re-embarks on a damning analysis of any potential suitors:

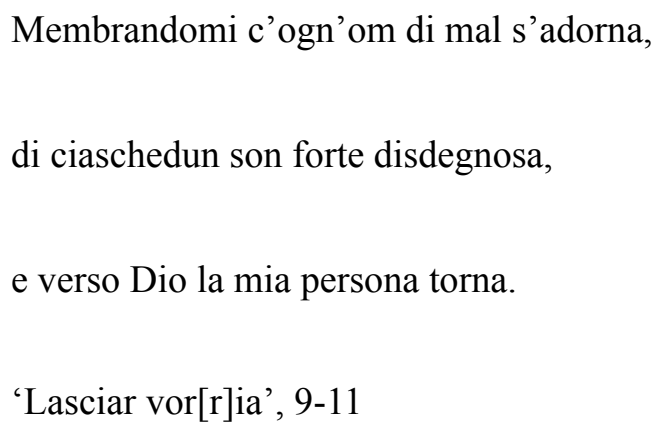

Echoing the pivoting chiasmus of the octave, the Compiuta Donzella here offers an account of conversion as stage-direction, the physical turning her embodied self towards God and offering a version of the feminine speaker who stands in righteous judgement over the moral failings of men. While 'ogn'om' could conceivably represent a neutral generality (humanity), the context of the octave and the stance of the speaker in this first tercet strongly argue for this term as referring specifically to all men as a gendered group. Not only is the possibility of marriage resisted because the speaker has no choice, but also because all possible spouses are morally objectionable. Similarly, the speaker's authority to judge these men is presented as predicated on something that is itself gendered (grammatically, poetically, and socially) in a key adjective: 'disdegnosa'. The Compiuta Donzella appropriates a generic descriptor of the disdainful courtly lady in a move that subverts the norms of male-female power dynamics in the lyric context in two crucial ways. Firstly, in self-describing as 'disdegnosa', rather than being labeled as such by a masculine lover-poet whose advances she has rebuffed, this speaker reclaims a right to exercise judgement and, in finding men wanting, to express disdain. Secondly, in building on the moralising of the octave, this speaker is able to present her 
disdain as considered, morally justified, and rational, in opposition to the portrayals of a capricious lady's arbitrary whims common to the love lyric authored by men. The speaker's authoritative cataloguing of social ills and male failings offers the unavoidable argumentative backing to her position while also serving as a riposte to some of the misogynistic aspects of the lyric tradition.

It is also in adopting this mantle of disdainful judgement that the io of the speaker comes into focus. In a rhetorical and thematic echoing of the strategies of selfrepresentation we saw at play in 'A la stagion', the first-person pronoun, introduced at the moment when the 'marito' is resisted, establishes the speaker's gendered identity against the other of the putative husband. It also serves as a catalyst for a slew of inward-turning, first-person pronouns and possessives ('mia volontate', 'membrandomi', 'la mia persona'), which continue into the final tercet:

Lo padre mio mi fa stare pensosa, ca di servire a Cristo mi distorna: non saccio a cui mi vol dar per isposa.

'Lasciar vor[r]ia' 12-14

Possessive adjectives and the nouns they qualify occupy key spaces in the structure of the text as it tracks from the will that resists to the self that turns towards God to the father who turns the speaker away from her desired object, Christ. This process is emphasised by the contrapuntal rhyming of 'torna'/'distorna'. 'Mia volontate' closes the octave, while 'mia persona' comes in the final line of the first tercet and is reprised and reversed in '[1]o padre mio' at the beginning of the second. This inversion is even more 
marked in the manuscript, in which sonnets are laid out with two verses to each line, rendering verses 11 and 12 on a single line as the possessives of 'la mia persona' and '[1]o padre mio' pivot around the verb tornare. ${ }^{23}$ The twisting chiasmus of the possessives mia/mio in relation to the nouns they modify, reflects on a syntactic level the father's role in turning the speaker away from the service of Christ and towards an unwanted marriage. So even as the speaker asserts a subjective identity, she also enunciates her subject state along the traditional axis of patriarchal, familial power, and it is undeniable that the poem foregrounds the potential lack of agency of young women in matters of marriage and love.

This father-daughter power dynamic is, however, critically framed against the Father-Son axis of God and Christ. This second tercet clearly highlights the power of the father in the negotiation of marriage, even as it reinforces the strident contrast between God and her father, her father's will and her own, and her role as bride of man and as monastic bride of Christ. The proximity of '[1]o padre mio' and 'Cristo', necessarily puts us in mind of liturgical and Christian framings of the Father and the Son, as does the internal rhyme created between 'e verso Dio' and '[1]o padre mio' (11-12). This frame is then subverted by the role of the speaker's father in turning her away from

${ }^{23}$ The layout of the tercets as transcribed from the facsimile edition of the Vatican Canzoniere (Vat. Lat. 3793) in I canzonieri della lirica italiana delle origini, ed. by Lino Leonardi , 4 vols, (Florence: SISMEL, 2001) I, f. 129v, appears as follows (italics mine): Membrandomi congnomo dimale sadorna $\cdot$ diciascheduno sono forte disdegnosa $\cdot$ eversso dio lamia p [er] sona torna $\cdot$ lo padre mio mifa stare pensosa $\cdot$ cadiservire acristo mi distorna $\cdot$ nonsaccio achui mi vole dare perisposa $\cdot$ This format is common in early MSS renderings of the sonnet, not least in Petrarch's holograph MSS. For an expansive discussion of textual layout and 'visual poetics', see H. Wayne Storey, Transcription and Visual Poetics in the Early Italian Lyric (New York: Garland, 1993). 
Christ, a counterpoint again reinforced by the rhyme between her desire ('la mia persona torna', 11) and her father's actions ('mi distorna'). A further twisting of the figure of God the Father can also be seen at play here; the speaker resists her father's will due to her love of Christ, while Christ was willingly sacrificed in accordance with his Father's will ('voluntas eius qui misit me' [the will of him that sent me]). ${ }^{24} \mathrm{By}$ framing the speaker's dilemma in this way, the Compiuta Donzella stages a conflict between the claims of two sets of grammatically masculine figures (the prospective husband and Christ/the father and God).25 This tension between the wills of fathers and children brings us back to the centrality and subversion of the subject's will in the quatrains and 'mia voluntate' is contrasted with the will and power of the father. In the sestet's acknowledgment of parental power, then, we are presented with a perverted Lord's Prayer, in which the father turns the child away from a devoted religious life.

The vigorous anti-marital, pro-religious sentiment of the speaker in 'Lasciar vor[r]ia' goes some way to explain the marvel displayed by Guittone d'Arezzo as he addresses the Compiuta Donzella and praises her miraculous piety:

Soprapiaciente donna, di tutto conpiuto savere, di pregio coronata, degnia mia Donna Conpiuta [...] Gientil mia donna, l'onipotente Dio mise in voi sì merav-

24 This formulation is found in the Vulgate text of John 4:34, 5:30, 6:38-39, each of which report Christ's desire not to do his own will, but God's, also indicative is Galatians 1:3-4, ‘3. Domin[us] nost[er] Ies[us] Christ[us] 4. qui dedit semet ipsum pro peccatis nostris ut eriperet nos de praesenti saeculo nequam secundum voluntatem Dei et Patris nostri' [3. our Lord Jesus Christ 4. who gave himself for our sins, that he might deliver us from this present wicked world, according to the will of God and our Father].

${ }^{25}$ While God's grammatical masculinity does not denote a straightforward masculine-gendering, further exploration of the implications of this lies outside the scope of this essay. The language of paternal-filial relationships in play in the Compiuta Donzella's sonnets and the definition of the Trinity, as well as the established image of Christ as Bridegroom, however, make for a productive comparison in this context. 
igliosamente conpimento di tutto bene, che maggiormente senbrate angelica criatura che terrena, in ditto e in fatto e in la sembian[sa] vostra tutta.

Letter V.1-2 26

As well as betraying an almost stilnovist flourish in Frate Guittone's prose writing (the figure of the angelic lady being a key topos in post-Guittonian poetics), ${ }^{27}$ this letter shows Guittone reading and praising one particular version of the Compiuta Donzella's textual output, one that aligns with his own priorities as moral and religious poet. There is also, perhaps, a hint of misogyny (and certainly a dose a paternalism) ${ }^{28}$ in Frate Guittone's marvel. The Compiuta Donzella is presented as worthy precisely because she is a miraculous figure ('mirabile fighura', V.3), unlike any other that has lived in this generation ('intra l'umana gennerassione d'esto seculo mortale', V.3), and therefore distinct from and surprising among the other members of her gender: 'Or donque, gientile mia Donna, quanto el Signor nostro v’à maggiormente allumata e smirata a conpimento de tutta presiosa vertute più c'altra donna terrena' (Letter V, 21-5). The over-the-top play on 'conpiuta' and its cognates is both typically Guittonian and serves to emphasise that the Compiuta Donzella is exceptional, while safely contained within the realm of wom-

${ }^{26}$ Guittone d'Arezzo, Lettere, ed. by Claude Margueron (Bologna: Commissione per i testi di lingua, 1990), pp. 85-91. See also the recent parallel translation in Guittone d'Arezzo: Selected Prose and Poetry, ed. and trans. by Antonella Borra (Toronto: University of Toronto Press, 2017) pp. 26-29.

27 The 'donna angelicata' comes into her own as trope with Guido Guinizzelli's praise poetry and is most clearly articulated in his canzone 'Al cor gentil', when the poet defends his love poetry before God on the basis that his lady resembled an angel ('Tenne d'angel sembianza', 58). Cavalcanti will riff on the lady as angelic creature ('angelicata crïatura', 'Fresca rosa novella', 18), with Dante reaching new heights in his representation of Beatrice.

${ }^{28}$ See Steinberg, 'La Compiuta Donzella', p. 23, on Guittone's self-styling as 'padre confessore' in this letter. 
anly virtue.

\section{Exchange and Exceptionality}

Guittone's thirteenth-century judgement has been echoed among some far less historically distant scholarly writing on the Compiuta Donzella, and is distilled in Chiari's mid-twentieth-century assessment: 'nei versi che si legano a quel nome [la Compiuta Donzella] nulla è che non convenga ad una donna, piena di gentilezza, dolce ed elegiaca, trepida e fragile, espansiva e pudica, veramente donzella e veramente compiuta' ${ }^{29}$ This double-edged marvel-as-containment is evident in a number of the other responses to the Compiuta Donzella's poetry by her contemporaries, and contributes to Steinberg's assessment of her treatment in the men's writing addressed to her in the Vatican Canzoniere as a sort of process of exorcism, by which her position as woman writing poetry can be 'diagnosed' as extraordinary and thus somehow dispelled. ${ }^{30}$ These 'exceptionalising' texts include the verse missive and response of an anonymous man poet, which are recorded on the recto of folio 170 of the same Vatican Canzoniere, as part of an exchange with the Compiuta Donzella herself.

This tenzone between the Compiuta Donzella and her anonymous interlocutor (comprising 'Gentil donzella somma ed insegnata', 'Ornato di gran pregio e di valenza', and 'Perc'ogni gioia ch'è rara è graziosa') has more than once fallen by the wayside in

\footnotetext{
${ }^{29}$ Alberto Chiari, 'La Compiuta Donzella', in Indagini e letture (Florence: Le Monnier, 1954), $1-7$ (p. 5).

${ }^{30}$ Steinberg, 'La Compiuta Donzella', pp. 24-26 and pp. 30-31.
} 
discussions of her work, though the exchange is discussed in other contexts. ${ }^{31}$ In part this omission is due to its shift in tone and theme and the difficulty of fitting the Compiuta Donzella's contribution into the framework of a biographical narrative of the sort that the present reading resists. ${ }^{32}$ Having accepted 'A la stagion' and 'Lasciar vor[r]ia' as poetic performances, rather than autobiographical outpourings, it becomes far simpler to view the tenzone within the spectrum of the Compiuta Donzella's textual legacy, rather than as a thorn in the side of biographical readings of her other poems. In this sonnet exchange the Compiuta Donzella engages in an ostensibly courteous exchange, modestly accepting the praise (and advances?) of her anonymous lyric suitor. Several aspects bear teasing out from this short dialogue: the anonymous poet's acknowledgement of and professed surprise at the figure of a woman poet, the language in which the masculine interlocutor frames his praise, the linguistic connections between this exchange and the Compiuta Donzella's other texts, and the potential ironies of the Compiuta Donzella's response read through the lens of a courtly lyric game.

Gentil donzella somma ed insegnata,

poi c'ag[g]io inteso di voi tant'or[r]anza, che non credo che Morgana la fata né la Donna de[1] lago né Gostanza

${ }^{31}$ Olive Sayce situates the opening salvo of the tenzone, along with Maestro Torrigiano's 'Esser donzella di trovare dotta' in her anthological history of exemplary comparative strategies, in Olive Sayce, Exemplary Comparison from Homer to Petrarch (Suffolk: Brewer, 2008), pp. 290 and pp. 313-14.

32 Kleinhenz, for instance, focuses on the Compiuta Donzella within the tradition of poetry complaining of bad marriages, while Chiari reads her poems in a biographical key and passes rapidly over the tenzone in favour of the 'confessione in due tempi' (p. 1) of 'A la stagion' and 'Lasciar vor[r]ia'). 
né fosse alcuna come voi presc[i]ata;

e di trovare avete nominanza

(ond'eo mi faccio un po[ca] di mirata

c'avete di saver tant'abondanza):

'Gentil donzella', 1-8

The tone of the anonymous correspondent is in line with Frate Guittone's treatment of the Compiuta Donzella's exceptionality and the first quatrain stacks name upon name of mythical and exemplary women, each of whom is less prized, says the speaker, than his addressee. Indeed no woman can compare, according to this missive, to the borderlinemiraculous woman poet. This mounting, comparative (perhaps wilfully excessive) praise in the first quatrain is coupled with the double-edged compliment of professed surprise at having heard of a woman so adept in poetry and so steeped in learning in the second. And here we may trace a misogynistic agenda underlying this incredulity, which Steinberg has identified in his reading of the Compiuta Donzella within the context of the feminine-voiced lyric of the Vatican Canzoniere, a context in which men repeatedly ventriloquise feminine voices for their own argumentative ends. These attempts to account for and sideline the Compiuta Donzella bely an anxiety around the successful performance of a feminine subject. The spectre of a woman poet need only be exorcised if it successfully troubles the status quo. ${ }^{33}$ The Compiuta Donzella does trouble norms, both thematically and by dint of her presence in the Italian vernacular lyric landscape (even though precedents exist in the trobairitz whose work circulated in Italian manu-

${ }^{33}$ Steinberg, 'La Compiuta Donzella', pp. 24-25. 
scripts). ${ }^{34}$ As such it shouldn't be surprising that the anonymous interlocutor of the tenzone at hand both follows the trend for treating the Compiuta Donzella as exceptional and attempts to contain her within the norms of lyric exchange; she must present the object of amorous advances, not the vocal lyric subject.

The backhanded compliment of the quatrains thus segues into the proposition of the tercets:

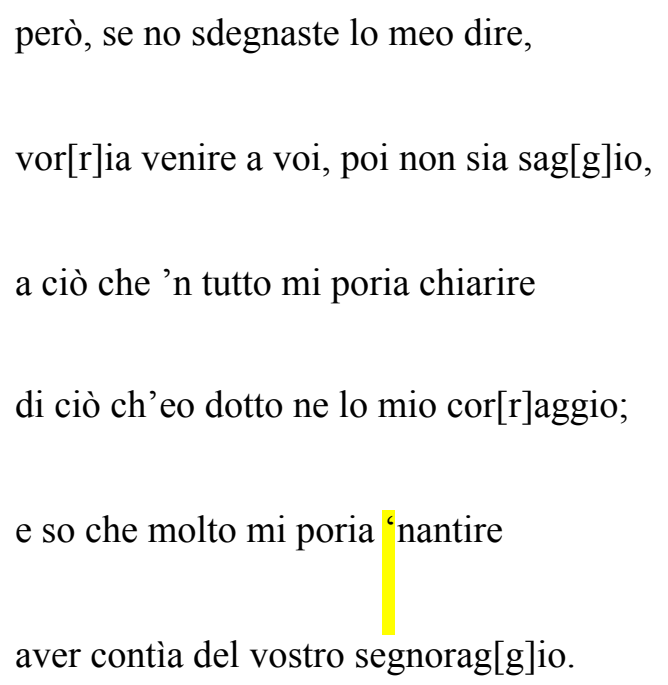

The anonymous interlocutor suggests that he come to make the acquaintance of Compiuta Donzella, so that he might be raised up by her mastery (a deferent proposal still soured by the backhandedness of the octave, and likely not uneuphemistic...). Beyond the marvelling tone, however, there is a sense of this text echoing the Compiuta Donzel-

34 For discussions of the trobairitz and relevant bibliography, see Roy Rosenstein, 'Ubi Sunt? Three Lost (and Found) Ladies in Troubadour Lyric', in Medieval Constructions in Gender and Identity: Essays in Honor of Joan M. Ferrante ed. by Teodolinda Barolini (Tempe: Arizona Center for Medieval and Renaissance Studies, 2005) pp. 87-102 (especially pp. 94-102), and The Voice of the Trobairitz. On the presence of trobairitz in Italian MSS, see Katherine Travers, 'Founding a Female Canon?: Women Lyric Poets of the Middle Ages' (paper presented at the Women and the Canon Conference, Oxford, 22-23 January 2016). 
la's poetic reputation and output. Two terms seem to play off concerns found in the Compiuta Donzella's sonnets considered thus far: the verb 'sdegnare' and the noun 'segnoraggio'. As we have seen, questions of 'signoria' are at the heart of the feminine speaker's plaints in both 'A la stagion' and 'Lasciar vor[r]ia', while the self-identification as 'forte disdegnosa' in 'Lasciar vor[r]ia' is at the heart of a rhetoric of gendered moral judgement. The anonymous interlocutor deploys both these terms in their typical courtly state, laden with the norms of erotic lyric exchange and power according to which Love and the lady have the upper hand, but any resistance to the lover-poet's advances is classified as negative through the language of pride or disdain. This is precisely the sort of lyric commonplace that the Compiuta Donzella has undermined in her use of the language of power (as real, social, and held by fathers and husbands) and disdain (as justified moral position in the face of the moral failings of men) in her other sonnets. While the question of the chronology of these texts may remain unanswerable, these resonances are worthy of comment, arguing for the place of the Compiuta Donzella's texts within a broader lyric field (a placement already implied by their inclusion in the Vatican Canzoniere).

The speaker in the Compiuta Donzella's response to 'Gentil donzella somma ed insegnata' appears to take the stance of a modest lyric lady, accepting both the ostensible praise and the advances of the anonymous sonnet:

Ornato di gran pregio e di valenza

e risplendente di loda adornata,

forte mi pregio più, poi v'è in plagenza

d'avermi in vostro core rimembrata 
ed invitate a mia poca possenza

per acontarvi, s'eo sono insegnata,

come voi dite, c'agio gran sapienza,

ma certo non ne sono amantata.

Amantata non son como voria

di gran vertute né di placimento;

ma, qual ch'i' sia, agio buono volere

di servire con buona cortesia

a ciascun ch'ama sanza fallimento:

ché d'Amor sono e vogliolo ubidire.

In the final tercet's promises of service and obedience, the Compiuta Donzella's text opens further intertextual possibilities for this tenzone, deploying a number of terms and themes that characterise the rest of her surviving corpus. The language of service ('servire' and the related term 'ubidire') respond to those same issues of 'signoria' raised by the male interlocutor, and which occupy the Compiuta Donzella's attention in her other sonnets. The key difference in the context of this exchange is that service is the speaker's to grant or withhold and is reminiscent of the promises of service offered by the masculine courtly lover to the lady. Furthermore, by emphasising the voluntary nature of her obedience to Love ('vogliolo ubidire') and capitulation to the lover (common to the erotic lyric world depicted in the quatrains of 'A la stagion'), the Compiuta Donzella's text proposes exactly the kind of optional relationship that is denied to the speaker in her other texts. 
The language of service in the courtly (rather than the social, marital) sphere applies as much, if not more often to masculine lovers in relation to the lady (donna/domna/domina). Even in this response then, we do not see the typical tone of the lady acquiescing to the beloved in the tradition of contrasti or pastourelles, and nor do we see the sort of overt comic invective encountered in Guittone's 'donna villana' sonnets, or Cecco Angiolieri's dialogue sonnets with Becchina. 35 The absence of the crass parody and lewd slanging matches of those comic verses does not, however, prevent the Compiuta Donzella from engaging in a (thinly) veiled critique of courtly tropes. For, far from being a simple acceptance of the lover, the speaker in this apparent capitulation sows the seeds of an irony to match the backhandedness of the anonymous sonnet to which it responds. In the closing promise to serve anyone who loves without fault, there is the implicit threat not to serve anyone who falls short, and we have seen, in the condemnations of a speaker who is 'forte disdengosa' in 'Lasciar vor[r]ia', that men suffer from a tendency to faultiness ('c'ogn'om di mal s'adorna', 9). This promise also calls on the language of will and willingness that has characterised the plaints of the Compiuta Donzella's other sonnets. While in the marriage sonnets the speaker's 'volontate' and 'voglia' were pitted against the edicts of the father and the prospective lordship of a husband, here the positioning of the language of will in the third line of each tercet ('agio buono volere', 'voglio ubidire') again emphasises its importance in 'Ornato di gran pregio'. Here, though, actions take place according to the speaker's will, not against it. There is no-one to turn the lady away from her desired outcome. Service is not a given, the

\footnotetext{
35 For the anti-courtly irony of Guittone's texts see Tristan Kay, 'Redefining the "matera amorosa": Dante's Vita nova and Guittone's (anti)courtly "canzoniere"”, The Italianist, 29 (2009), 369-399, and for both Guittone's and Cecco's texts with commentary, see Poesia Comica del Medioevo Italiano, ed. by Marco Berisso (Milan: Rizzoli, 2011).
} 
speaker will not give herself, or be given over to the lover without her say so, which is dependent on her will and consent, not her father's designs and her suitor's desires. The feminine speaker is as clear on her will as in the Compiuta Donzella's other sonnets, the key difference being her ability to follow it.

The response of the Compiuta Donzella's anonymous interlocutor is laden with courtly commonplaces and addresses her directly in the second line, while excusing his late reply in a flowery, apparently flattering apology:

Perc'ogni gioia ch'è rara è grazïosa,

mi son tardato, Compiuta Donzella,

d'avere scritto a la vostra risposa

la qual faceste a me fresca e novella.

'Perc'ogni gioia', 1-4

In this opening quatrain we see a return of the language of strangeness and novelty ('novella', both doubling the sense of 'fresca' and carrying an implication of something remarkable), which characterised this correspondent's opening poem and many of the other thirteenth-century references to the Compiuta Donzella. ${ }^{36}$ The portrayal of the Compiuta Donzella's 'novelty value' found in these contemporary responses to her work further props up accounts of her as exceptional, atypical.

The apologetic exordium gives way to a readerly response to the Compiuta Donzella's own 'risposa', which, according to this poet-cum-critic demonstrates those talents promised by her reputation:

\footnotetext{
${ }^{36}$ See note 11 above.
} 
E ben si testimonia, per la losa

che di me usaste, che voi siete quella

in cui altezza e gran valor riposa:

cotal a[1]bor mostr' alto sua fior bella.

Sua fiore bella e d'amare lo frutto

mostra 'n altezza com'è d'alto stato:

però in gioia $a b[b]$ o detto tutto,

e pregovi che mi sia perdonato

s'io m'invitai laove sone al postutto

ch'io non son degno d'esser presentato.

'Perc'ogni gioia', 5-14

The flower imagery of this response is indebted to lyric commonplaces as well as recalling the Compiuta Donzella's own textual history. The sirma capfinida - 'sua fior bella. / Sua fiore bella' - connecting lines 8 and 9 riffs on a floral image of the Compiuta Donzella's beauty as the flower high on the tree, with love as the fruit thereof. The sexual overtones here are barely overtones, but there is also an intertextual suggestiveness in play. ${ }^{37}$ In 'A la stagion', the Compiuta Donzella both set up the floral backdrop of the courtly plazer and made clear the lack of comfort she took in that flowery world of lovers. On the formal level too, the doubled phrases between quatrain and sestet recall the Compiuta Donzella's deployment of the connective 'non ne sono amantata./Aman-

37 Catenazzi notes the parallel in his notes to 'Perc'ogni' gioia': Flavio Catenazzi, Poeti fiorentini del duecento (Brescia: Morcelliana, 1977), pp. 153-169 (p. 168). 
tata non son' ('Ornato di gran pregio' 8-9), forging a link not just between octave and sestet, but between this sonnet and the text to which it responds. While our anonymous correspondent does not reprise the Compiuta Donzella's rhyme scheme (as was common for many tenzoni), he does deploy structural mimicry to cement his sonnet's status as response.

Another sonnet, variously attributed to Guido Guinizzelli (including by Contini) and Maestro Rinuccino (most ardently by Carrai), ${ }^{38}$ is commonly supposed to be addressing the Compiuta Donzella. This supposition becomes yet more convincing when we note the close textual resemblances it bears to our tenzone:

Gentil donzella, di pregio nomata,

degna di laude e di tutto onore,

ché par de voi non fu ancora nata

né sì compiuta de tutto valore,

pare che 'n voi dimori onne fiata

la deïtà de l'alto deo d'amore;

de tutto compimento siete ornata

[e] d'adornezze e di tutto bellore:

ché 'l vostro viso dà sì gran lumera

che non è donna ch'aggia in sé beltate

ch'a voi davante non s'ascuri in cera;

38 Contini, II, 474; Carrai, I sonetti di Maestro Rinuccino da Firenze (Florence: Accademia della Crusca, 1981), pp. 118-124, as noted in Steinberg, 'La Compiuta Donzella', p. 2. 
per voi tutte bellezze so' afinate,

e ciascun fior fiorisce in sua manera

lo giorno quando vo' vi dimostrate.

This sonnet shares, as Steinberg notes, some of the language of Frate Guittone's letter to the Compiuta Donzella. ${ }^{39}$ It also, and perhaps most significantly, posits itself as a per le rime participant in the Compiuta Donzella's tenzone with the anonymous poet of 'Gentil donzella somma ed insegnata' and 'Perc'ogni gioia'. In adopting rhymes of the first two sonnets in the tenzone, it goes beyond mere association or response-at-a-distance to instead offer a conscious dialogic engagement with the Compiuta Donzella's writing. In addition to mimicking the -ata rhyme of the first anonymous sonnet and the Compiuta Donzella's reply, 'Gentil donzella, di pregio nomata' also picks up the semantic keys of 'ornata/adornata', 'pregio', 'bellezza/beltate', 'fiore', 'loda/lauda', 'valore', and, of course the embedded 'compiuta'. This additional sonnet from a masculine lover's perspective, presents itself as a text to which the Compiuta Donzella's sonnet could as easily offer a response as a provocation. As with 'Perc'ogni gioia', this sonnet seems to show awareness of at least one of the Compiuta Donzella's other texts, namely 'A la stagion'. This Rinuccino/Guinizzelli sonnet deploys floral imagery, which, in the repetitious 'fior fiorisce', is reminiscent of the 'foglia e fiora' motif of 'A la stagion'. This echo, taken together with the points of lexical contact with the tenzone, is lifted out of the generic and into a more particular intertextual rapport with the Compiuta Donzella's language and rhetoric. The semantic field of adornment and value ('pregio') also serves both to tie 'Gentil donzella, di pregio' to 'Ornato di gran pregio', with its opening line,

\footnotetext{
${ }^{39}$ Steinberg, 'La Compiuta Donzella', p. 2.
} 
and its double 'amantata' (8-9), and to bring to mind the Compiuta Donzella's other sonnet, 'Lasciar vor[r]ia'. That sonnet also played on ideas of worth and adornment ('ed ancor senno e cortesia morire/e lo fin pregio e tutta la bontate', 5-6, 'c'ogn'om di mal s'adorna', 9), though all the while looking towards Christ and God on high, rather than the lofty god of love ('la deïtà de l'alto deo d'amore', 'Gentil donzella, di pregio', 6).

Given that both 'Perc'ogni gioia' and 'Gentil donzella, di pregio nomata' engage with semantic fields that are explicitly overturned or countered in the Compiuta Donzella's own 'A la stagion' and 'Lasciar vor[r]ia', we are left with the impression of linguistic and semantic reflections across the anonymous tenzone, the additional response, and the Compiuta Donzella's other poems. These commonalities, especially as they turn on lyric commonplaces, the language of service, and the foregrounding of the will, also allow us to consider her surviving texts as treating a shared spectrum of features and themes through the versions of a feminine speaker that they perform.

\section{Conclusion}

The texts left to us, attributed to the first woman poet in the Italian tradition, do not exist in a vacuum. The ripples caused by the Compiuta Donzella's presence on the peninsula's early lyric scene extend further than the meagre corpus that survives in the illustrious context of the Vatican Canzoniere. She is engaged in tenzone and appears in a halo of poetic and prose texts, a sample of which have been treated above and many of which are tinged with double-edged incredulity at her qualities or erudition and moral rectitude. These attitudes were also reflected in much earlier scholarship on her poetry, which placed emphasis on her 'propriety', 'femininity', skill, while questioning her very existence. Far greater subtlety and interpretive rigour has emerged more recent research, 
while further work on the Compiuta Donzella's texts within the wider tradition of women writing in medieval Europe remains to be done, and indeed is ongoing. 40 The present study has aimed to build on these emergent formal and contextual analyses of her texts in order to bring into sharp focus her performance of a feminine subject against the norms of social power and erotic lyric dynamics. Closer analysis, in particular of the ways in which the Compiuta Donzella performs that subject, emphasises the poet's critical engagement with lyric tropes and the language of power and allows us to situate them as an inter-related corpus within a broader tradition of erotic lyric and textual exchange. The Compiuta Donzella's works, analysed alongside texts by those who read them, display a series of playful, ironic, moral, rhetorically deft lyric positions — versions of a feminine voice - through which an explicitly, precisely-gendered speaker, written by a woman poet, critiques and resists, both obliquely and explicitly, the language and postures of male-authored, masculine-voiced love lyric.

40 The present article is part of my longer-term research into representations of feminine voices in the early Italian tradition. Elsewhere, Travers has proposed a comparative study of manuscript sources of women writers in the Italian and Old Occitan traditions to shed some light of the preservation, circulation, and status of women's writings among Italian readers and scribes (see note 34 , above). 